\title{
Costs of Foreign Capital Flows in Emerging Market Economies: Unexpected Economic Growth and Increased Financial Market Volatility
}

\author{
Kyoungsoo Yoon* \\ Jayoung Kim**
}

The views expressed herein are those of the authors and do not necessarily reflect the official views of the Bank of Korea. When reporting or citing this paper, the authors' names should always be explicitly stated.

\footnotetext{
* International Finance Research Team, Bank of Korea, Seoul, Korea (kyoungsoo.yoon@bok.or.kr)

** Economic Research Team, Busan Branch, Bank of Korea, Busan, Korea (jyk@bok.or.kr)
}

The authors would like to thank Woon Gyu Choi, Seung Je Hong, Chanho Park, Dae Jung Yang, Soyoung Kim, and participants in the $3^{\text {rd }}$ International Finance Forum hosted by the Bank of Korea and in a BOK seminar for their helpful comments. 


\section{Contents}

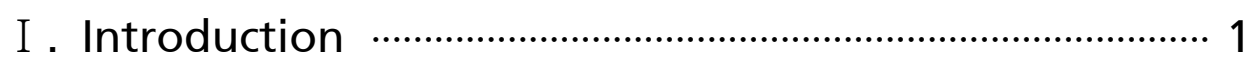

II. Effects of Foreign Capital Flows on GDP Growth Surprises ………………………………………….. 5

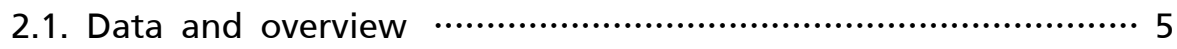

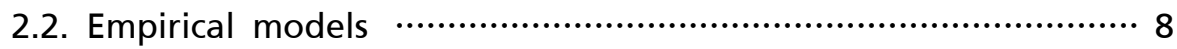

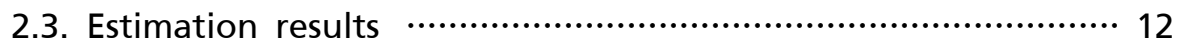

III. Effects of Foreign Capital Flows on Financial Market Volatility ………………………………………….... 16

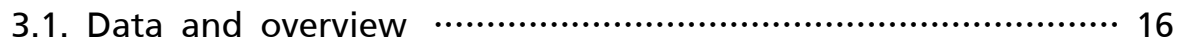

3.2. Empirical models …………................................................ 17

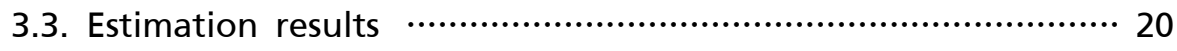

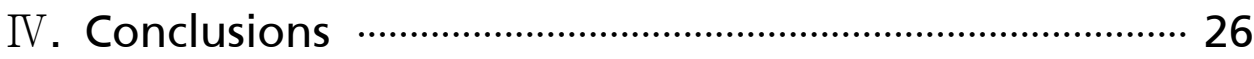

References

Appendix 


\section{Costs of Foreign Capital Flows in Emerging Market Economies: Unexpected Economic Growth and Increased Financial Market Volatility}

The high volatility of economic growth and financial markets in emerging market economies following large swings in foreign capital flows over the past 10 years highlights their possible related costs. This paper investigates the impact of foreign capital flows on GDP growth surprise (= realized GDP growth rate expected GDP growth rate) and financial market volatility. We find that FDI and foreign bank loans are positively associated with unexpected GDP growth on a contemporaneous basis, while increases in foreign bond and equity investment induce lower GDP growth than expected in the following year.

Volatility in all four types of foreign capital flows is positively related to stock market volatility only in the case of a crisis. Volatility in bank loans is likely to have a larger impact here than will volatility in equity investment. Higher volatility in FDI, foreign equity investment and bank loans amplify foreign exchange market volatility during a crisis while mitigating it during a non-crisis period. The volatility of foreign bond investment meanwhile has the strongest positive effect on foreign exchange rate volatility in the case of a crisis, but has no effect in a non-crisis period. The possible costs of foreign capital flows in EMEs should incentivize policymakers to introduce capital flow management measures or macroprudential measures, in order to ensure macroeconomic stability as well as financial stability.

Keywords: Foreign capital flow, GDP growth surprise, Stock price volatility, Foreign exchange rate volatility

JEL Classification: E2, F21, F3, G1, O47 


\section{I . Introduction}

Past studies and neoclassical theory predict a positive effect of increased foreign capital inflows on economic growth - both indirectly through collateral benefits such as financial market development and improved institutions, as well as directly through increased investment and subsequent capital accumulation with lower costs.1) In other words, the majority of the previous literature has focused on the benefits of capital account liberalization and subsequent inflows of foreign capital.

However, empirical studies show that the effects of foreign capital flows on economic growth are neither conclusive nor always positive, and it often depends upon the types of flows. Emerging market economies (EMEs) experienced a rapid exodus of foreign capital during the Global Financial Crisis in 2008-09, while rising tides of foreign capital had flowed in before the crisis and did so again after it. These large swings of foreign capital flows in EMEs have frequently led to more volatile economic growth and often been associated with skyrocketing financial market volatility, especially during the crisis, highlighting the possible costs of foreign capital flows.

In this regard, we try to assess the costs of foreign capital flows in terms of their impacts on economic growth and financial market volatility. One issue is that any subsequent decrease in economic growth stemming from a contraction in foreign capital flows, if it occurs, cannot be fully regarded as a cost of foreign capital flows. This is because any negative growth effect from outflows of foreign capital will be offset to a large extent by the previous positive growth effect from their inflows, as long as foreign capital flows are positively related to economic growth. To address this issue, we introduce 'GDP growth surprises (= realized GDP growth rates expected GDP growth rates).' If GDP growth surprises, i.e. unexpected GDP growth rates, turn out to be positively related to foreign capital flows, we can regard an unexpected GDP growth rate caused by foreign capital flows as a cost to the recipient economy. This view makes our paper unique in analysing the real effect of foreign capital flows in EMEs.2) It is comparable to distinguishing the

1) Refer to Kose et al. (2009) and BIS Committee on the Global Financial System (CGFS) (2009) for details.

2) Kim and Mitra (2014) use GDP growth surprises to examine the real effects of funding vulnerabilities in cross-border banking linkages. They find that funding vulnerability is related to positive GDP growth surprises during normal periods, while being related to negative GDP surprises during crisis periods. 
amount of the business cycle amplification due to the financial cycle, as suggested in Claessens et al. (2011) and Borio (2014).

On the other hand, we do simply consider the increase in financial market volatility caused by foreign capital flows as a cost, even though some portion of it results from efficient resource allocation which does not harm the economy. In this paper volatility is chosen as one measure of a cost in terms of the harm to financial stability. The advantage of using volatility as a measure of cost is that it has intensity, while episodes such as surges and stops or crises are measured as basically binary variables. In our analysis, specifically, foreign exchange rate volatility and stock price volatility are used.

To analyze the impact of the four types of foreign capital flows - direct investment, bond investment, equity investment and bank loans - on GDP growth surprises, i.e. .unexpected GDP growth rates, we use a panel data set for 24 EMEs from 2005 to 2013. Another quarterly panel data set, of the same EMEs from 2005.Q1 to 2014.Q1, is used to analyze the relationships between foreign capital flows and financial market volatility. The data starts from 2005 because of the methodological changes in statistics on foreign capital flows in the balance of payment statistics from that time. We carefully choose 24 EMEs with similar degrees of financial market openness, which could affect the relationships between foreign capital flows and EMEs.

A novelty of this paper is its approach to mitigation of endogeneity issues mainly through its data choices. In the case of economic growth panel regressions, the dependent variable is GDP growth surprises (which are known only after the period under consideration has passed), which are assumed to not affect contemporaneous foreign capital investment while the effect running in the opposite direction remains valid. For our stock market and foreign exchange market volatility regressions, the conditional volatilities of foreign capital flows using Schwert (1989) are expected to influence the unconditional volatilities of stock prices and foreign exchange rates, while being uninfluenced by them. We also try to assess any differences, between normal times and crisis times as exemplified by the 2008-2009 Global Financial Crisis, in the impacts of foreign capital flows on unexpected economic growth rates and financial market volatility.

The main findings can be broadly categorized into three. First, an increase in 
FDI or foreign bank loans results in a higher GDP growth surprise (i.e. a higher GDP growth rate than expected) in a recipient EME. This implies that these two types of foreign capital flows in an economy tend to amplify fluctuations in its economic growth more than expected. A larger business cycle amplitude than expected is regarded in this analysis as a cost or a risk to an economy. There are no differences in results between non-crisis periods and the Global Financial Crisis period. On the other hand, we cannot find any evidence of statistically significant contemporaneous impacts of foreign equity or bond investment on unexpected GDP growth rates. However, an increase in foreign portfolio investment in the previous year does lead to a lower GDP growth surprise in the current year.

Second, higher volatilities of all types of foreign capital flows are associated with higher stock market volatility in EMEs only during the Global Financial Crisis. With the assumption of one standard deviation increases in volatility of all types of foreign capital flows, the volatility of foreign bank loans is likely to have a larger impact on stock price volatility than will that of equity investment. This result is consistent with the consensus wisdom that, during a period of global financial stress, a debt type capital flow is riskier for a recipient economy than an equity type flow. 3 )

Third, increases in volatility of FDI, foreign equity investment and foreign banking flows tend to amplify foreign exchange rate volatility during the crisis period, while in contrast causing it to decrease during non-crisis periods. In the case of foreign bond investment, an increase in its volatility induces expanded foreign exchange rate volatility only during the crisis, while there is no evidence of a relationship between the two variables during a non-crisis period. However, with the assumption of one standard deviation increases in volatility of all types of foreign capital flows, foreign bond investment volatility plays the strongest role in amplifying foreign exchange market volatility during the crisis. This result is consistent with the prediction of interest rate parity theory, explaining the relationship between bond yields and foreign exchange rates.

3) Montiel (2014) states that the probability of capital flow reversals depends upon the composition of external liabilities, and that there is a consensus on the "pecking order" of volatility among types of flows. Foreign currency debt is more volatile than equity flows, which have risk-sharing and self-correcting characteristics. 
This paper is broadly related to the literature on the effects on economic growth of capital account liberalization or capital flows. According to several literature surveys, such as Eichengreen (2001), Henry (2007) and Kose et al. (2009), cross country empirical results do not clearly support the positive effect of capital account liberalization on economic growth predicted by theory.4) Many studies including Arteta et al. (2003) and Henry (2007) try to reconcile the evidence with theory. They emphasize that a recipient economy's absorptive capacity, such as its degree of domestic financial market development and institutional quality, is important if it is to obtain benefits from foreign capital flows. ${ }^{5}$ ) While these studies focus on the benefits of capital flows stemming from their possible positive impacts on economic growth, our analysis examines the possible costs of foreign capital flows from the standpoint of their impacts on unexpected GDP growth.

In this vein, our paper is more related to the literature examining the vulnerabilities caused by capital flows. Reinhart and Reinhart (2008) showed that capital flow bonanza periods 6 ) are associated with higher incidences of crises in middle- and low-income countries. Caballero (2014) found that episodes of surging capital inflows were associated with subsequent banking crises regardless of the accompanying lending booms. ${ }^{7}$ ) Inasmuch as a crisis is generally accompanied by higher financial market volatility and lower economic growth, our results are broadly consistent with these findings. However, these studies only explored extreme episodes such as surges in capital inflows and subsequent crises, without discussing any role played by foreign capital flows during normal times. Our paper shows the effects of foreign capital flows on unexpected GDP growth, and on stock and foreign exchange market volatility, without limiting its analysis

4) The standard neoclassical growth model predicts that capital inflows to an emerging market economy through capital account liberalization reduce the cost of capital, and give rise thereby to subsequent increases in investment and growth. See Henry (2007).

5) See BIS CGFS (2009) for more details.

6) Reinhart and Reinhart (2008) defined periods of large current account deficits (\% of GDP) as capital flow bonanza periods. Thus, capital flows in their paper are the sum of resident capital flows (capital outflows) and foreign capital flows (capital inflows or gross capital inflows), i.e. net capital inflows, while our paper focuses only on foreign capital flows. Caballero (2014) uses both net capital inflows and gross capital inflows for his analysis.

7) Montiel (2014) analytically summarized the issues and policies related to capital flows. 
to such identified cases. This differentiates it from most of the existing literature.

Vo (2009), Choong et al. (2010), and Aizenman et al. (2013) directly assessed the effects of foreign capital flows $\left.{ }^{8}\right)$ on economic growth, without identifying such episodes. Vo (2009) found a positive effect of net private capital flows on economic growth in emerging Asian economies, while the latter two studies found possibilities of negative effects for some types of capital inflows. Choong et al. (2010) showed that foreign debt and portfolio investment initially have negative impacts on economic growth, although their signs can turn positive with the achievement of a certain level of stock market development. Aizenman et al. (2013) found short-term debt to be negatively associated with the recipient country's economic growth. Our study focuses not on any negative or positive growth effects of any type of foreign capital flows, but on the possible unexpected GDP growth effects - which we consider an inflicted cost because a larger rate of unexpected GDP growth implies an increase in uncertainty or business cycle amplitude in the recipient economy.

In the next section we discuss the effects of foreign capital flows on GDP growth surprises. In Section III we then examine the relationship between foreign capital flows and financial market volatility. In the final section, we conclude with a brief summary of our main findings and their policy implications.

\section{II . Effects of Foreign Capital Flows on GDP Growth Surprises}

\subsection{Data and overview}

To assess the effects of foreign capital flows on GDP growth surprises, we examine an annual panel data set of 24 EMEs from 2005 to 2013. Our data starts from 2005 since data on foreign capital flows is available from that year, when the methodology of the IMF BOP (Balance of payments) statistics was moved from

8) There are differences among these studies in terms of the capital flow data used. Vo (2010) and Choong et al. (2010) seem to use net capital flows (= capital inflows - capital outflows in the balance of payments statistics), while Aizenman et al. (2013) use foreign capital flows, disaggregated into FDI, portfolio investment, equity investment and short-term debt, together with capital outflows only for FDI. 
BPM5 to BPM6.9) We choose sample EMEs with similar degrees of financial account liberalization or financial market openness, since the relationship between foreign capital flows and economic growth can vary depending upon financial market openness. ${ }^{10)}$

To be specific, we first categorize 182 economies into three groups in accordance with their degrees of openness based upon their average values in the Chinn-Ito Financial Openness Index ${ }^{11)}$ from 2000 to 2012, and choose 60 economies from the middle group. Next we select 32 EMEs whose average annual GDPs are more than 20 billion US dollars (about $0.04 \%$ of World GDP) during the same period, and then narrow this group down to 22 economies ${ }^{12)}$ based on data availability. To enlarge our sample size we also include in our final sample of 24 EMEs Peru and Indonesia, which have higher levels of financial openness.

We use annual data for the analysis, in contrast to most empirical studies on economic growth that use long-run averages of more than or equal to five years. There are two reasons for this. First, our data covers only nine years, from 2005 to 2013, because of a break in the data on foreign capital flows as explained above. Second, movements of foreign capital flows are very fast and can be very large in short periods of time, making them unable to be analyzed with data summed or averaged over longer periods of time. For example, foreign equity investment into the 24 economies was around $-0.4 \%$ of GDP in 2008, but a similar amount of it returned to them in 2009. If we were to use the average for the two years, the two movements would be canceled out and missed in the analysis.

Three types of foreign capital flows - FDI (direct investment: liabilities), and equity (equity and investment fund shares: liabilities) and bond (debt securities:

9) For example, reinvestment of earnings of affiliates is explicitly specified in direct investment from BPM6. In 2012, retained earnings comprised about 29\% of foreign direct investment in 20 of our 24 sample EMEs excepting Brazil, Indonesia, Malaysia, and Vietnam.

10) Henry (2007) showed that capital account liberalization has a positive effect on economic growth just temporarily at around the time of liberalization. This implies that the size of the growth effects from foreign capital flows can vary across economies having different levels of financial account openness.

11) Refer to Chinn and Ito (2006).

12) Argentina, Brazil, Bulgaria, Chile, Colombia, Costa Rica, Croatia, Hungary, Israel, South Korea, Malaysia, Mexico, the Philippines, Poland, Romania, Russia, the Slovak Republic, Slovenia, Thailand, Turkey, Venezuela, and Vietnam. 
liabilities) investment - are from the financial account in the balance of payments statistics. Bank loans are from the BIS LBS (Locational Banking Statistics), ${ }^{13)}$ since we cannot differentiate bank loans from other investments in the IMF balance of payments statistics (which include trade credit and advances, currency and deposits, and others as well as bank loans). All types of foreign capital flows are expressed as percentages of GDP. The inflation rates based on the CPI (Consumer Price Index), current accounts (\% of GDP), and general government expenditures (\% of GDP) are from the IMF WEO (World Economic Outlook) database. The population growth rates, trade (imports and exports, \% of GDP), domestic credit to the private sector (\% of GDP), market capitalizations of listed companies (\% of GDP), and short-term external debt-to-FX reserves ratios are based on the World Bank database.

A GDP growth surprise is defined as the difference between a realized GDP growth rate and an expected GDP growth rate. GDP growth rate forecasts in the IMF WEO announced every April are used for the expected GDP growth rates. We try to analyze the effects of foreign capital flows on GDP growth surprises instead of actual GDP growth for two reasons. First, a GDP growth surprise is a better measure for assessing the costs of foreign capital flows in the recipient EMEs. A subsequent decline in GDP growth stemming from any contraction in foreign capital flows will be offset to a large extent by the positive effect from increased foreign capital flows in the previous periods. Thus we cannot consider all of the decrease in actual GDP growth a cost. However, if GDP growth surprises are estimated to be positively associated with foreign capital flows, we can regard unexpected GDP growth rates as a cost of these flows. A bigger absolute value of GDP growth surprise implies an increase in economic uncertainty. Second, GDP growth surprises can mitigate the endogeneity issue in the estimation which hampers analysis of any contemporaneous effects of foreign capital flows on economic growth. This will be explained in detail in the next subsection.

As can be seen in Figure 1, the correlations between GDP growth surprises and foreign capital flows vary across the different types of flows as well as over the crisis

13) The LBS (Locational Banking Statistics) provide quarterly data on international financial claims (loans and deposits) of domestic and foreign-owned banking offices resident in the 44 BIS reporting countries, by country of residence of the counterparty. 
Figure 1. Correlation between GDP Growth Surprises and Foreign Capital Flows

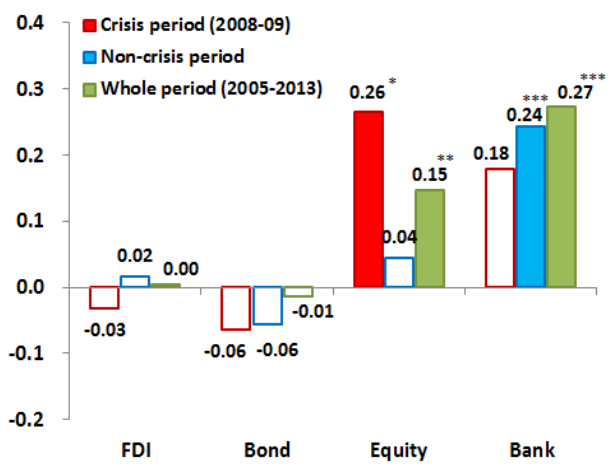

Note: $* * *, * *$ and * denote significances at the 1 , 5 and 10 percent levels, respectively.

Sources: IMF, BIS, World Bank and authors' calculations
Figure 2. GDP Growth Surprises and Realized GDP Growth Rates

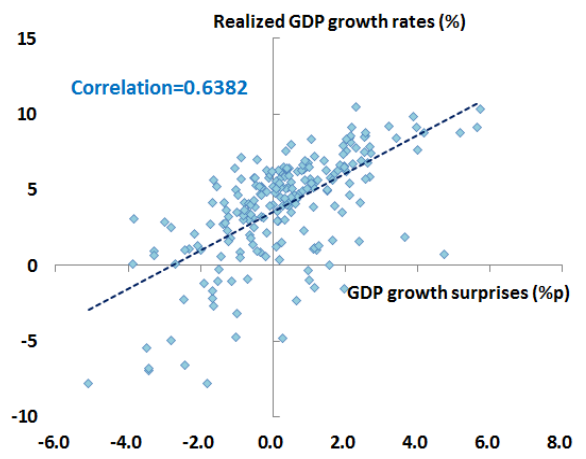

Sources: IMF and authors' calculations

and the non-crisis periods.14) This study thus examines each type of foreign capital flows instead of aggregating them, while trying to distinguish any differences in the results between a crisis period, here the Global Financial Crisis period of 2008-09, and a non-crisis period. It is notable that there is a high correlation between GDP growth surprises and realized GDP growth rates, as seen from Figure 2. With this result, it is possible to say that a positive effect of a type of foreign capital flows on GDP growth surprise is often translated into a similar effect on actual GDP growth.

\subsection{Empirical models}

During the Global Financial Crisis, many emerging markets experienced large outflows of foreign capital together with declines in their economic growth rates. Both before and after the crisis they also saw larger inflows of some types of foreign capital flows together with higher economic growth rates, as shown in

14) Two conspicuous trends in foreign capital flows to EMEs compared to the pre-Global Financial Crisis period are 1) a decrease in bank loans, and 2) an increase in bond investment. See Figure A.1. 
Figure A.1. During both crisis and non-crisis phases, before implementing any needed policies policymakers need to understand how much these large foreign capital movements affect their economic growth. However, contemporaneous effects of foreign capital flows on an economy are relatively less studied, with past studies having focused on extreme cases such as surges and consequent reversals that are only known or identified afterwards. One of the main reasons for this is that it is not easy to analyse contemporaneous effects without a serious endogeneity issue.

In this context, we use GDP growth surprises (= realized GDP growth rates expected GDP growth rates) to alleviate this issue. Since the expected economic growth of an economy is thought to be included as a variable in the function of foreign investors' decision-making, GDP growth surprises allow us to bypass any effects of expected GDP growth on foreign capital inflows. ${ }^{15)}$ In addition, a GDP growth surprise is fully known only after the period in which it occurs, since the realized GDP growth rate is announced afterwards. ${ }^{16)}$ Finally, we consider a panel regression model to assess the effects of foreign capital flows on GDP growth surprises in recipient EMEs. This model is:

$$
\begin{aligned}
y_{i, t}^{\text {surprise }} & =c+\alpha_{i}+\beta_{1} \text { Foreign CapitalFlows }_{i, t}+\beta_{2} X_{i, t-1} \\
& +\beta_{3} \text { Crisis }^{2008-09}+e_{i, t}
\end{aligned}
$$

where $y_{i, t}^{\text {surprise }}$ is an unexpected GDP growth rate in a given EME at time t, Foreign CapitalFlows $s_{i, t}$ a type of foreign capital flows or capital inflows, $X_{i, t-1}$ a set of control variables, and Crisis ${ }^{2008-09}$ a Global Financial Crisis dummy.

Four types of foreign capital flows - FDI, foreign bond investment, foreign equity investment and foreign bank loans - are used for four respective estimations of regression equation (1). Eight other control variables from various past studies

15) Past studies such as Vo (2013) mitigate the reverse causality from economic growth to capital flows using the generalized method of moments (GMM) in their panel regression estimations.

16) There is a limitation here, however, since some part of it is known and can possibly affect foreign capital flows during the period. 
and economic theory are included in the equation. ${ }^{17)}$ The inflation rate, measured as a percentage change in the CPI, is a proxy for economic stability. The current account as a percentage of GDP represents the dependency on external financing. ${ }^{18)}$ The general government total expenditure as a percentage of GDP is a measure of government size, which tends to have a detrimental effect on the private sector. ${ }^{19)}$ The population growth rate, which is not lagged, is expected to be positively related to aggregate economic growth. Trade openness is measured as the sum of exports and imports relative to GDP, and is expected to contribute to economic growth.

Domestic credit to the private sector as a percentage of GDP has been found to have either a positive or a negative effect on economic growth. King and Levin (1993) show a robust positive relationship between initial financial conditions and subsequent economic growth. Rousseau and Wachtel (2011), however, demonstrate with more recent data that the finance-growth relationship declines because an excessive provision of credit likely leads to a banking system crisis. Cecchetti and Kahrroubi (2012) find that the level of financial development has a positive effect on economic growth up to a point, after which the effect reverses. The market capitalization of listed companies as a percentage of GDP is another measure of financial development, which can serve as a substitute for finance through the credit markets. The ratio of short-term external debt to foreign exchange reserves is a measure of vulnerability to an external shock. Since it is expected to play a more important role during a crisis, we add an interaction term between it and the Global Financial Crisis.

17) We choose control variables mostly among those identified as determinants of economic growth, since we could not find any past studies identifying the determinants of GDP growth surprise with the exception of Kim and Mitra (2014) who used just one control variable, "vulnerability indices for credit risk or funding risk" calculated by themselves. However, the determinants of the two variables can be similar in that the correlation between them is high, as seen from Figure 2.

18) In general, the current account of an economy records a surplus if its domestic savings are greater than its domestic investment. In this case capital will flow out of the economy if its foreign exchange reserves do not change. In this context, the higher the current account is, the less the economy relies on external financing. According to Prasad et al. (2007), economies that rely less on foreign financing grow faster.

19) Refer to Cecchetti and Kharroubi (2012). 
Based upon various panel unit root test results, the trade openness and the credit-to-GDP ratio are found to be nonstationary. We thus exclude a country-specific time trend in the two data series, which allows us to have stationary data. ${ }^{20)}$ To lessen the endogeneity issue, all of the control variables with the exceptions of foreign capital flows, population growth and the crisis dummy are lagged.

This baseline model is expanded to include an interaction term between foreign capital inflows and the Global Financial Crisis, as written in regression equation (2). The expanded model is expected to capture any additional effect of capital inflows on GDP growth surprises during extreme events like the crisis:

$$
\begin{aligned}
y_{i, t}^{\text {surprise }} & =c^{\prime}+\alpha_{i}^{\prime}+\beta_{1}^{\prime} \text { Foreign CapitalFlows }_{i, t} \\
& +\beta_{2}^{\prime} \text { Foreign CapitalFlows }_{i, t} \times \text { Crisis }^{2008-09} \\
& +\beta_{3}^{\prime} X_{i, t-1}+\beta_{4}^{\prime} \text { Crisis }^{2008-09}+e_{i, t}^{\prime}
\end{aligned}
$$

Some types of foreign capital flows would need some time to affect economic growth, which is hinted at by the fact that many economic growth regressions in the literature are based upon low frequency data such as 5-year non-overlapping or basically cross-sectional data. We thus set up two regression models with lagged foreign capital flows, instead of our current ones, as follow:

$$
\begin{aligned}
y_{i, t}^{\text {surprise }} & =c^{\prime \prime}+\alpha_{i}^{\prime \prime}+\beta_{1}^{\prime \prime} \text { Foreign CapitalFlows }_{i, t-1}+\beta_{2}^{\prime \prime} X_{i, t-1} \\
& +\beta_{3}^{\prime \prime} \text { Crisis }^{2008-09}+e_{i, t}^{\prime \prime} \\
y_{i, t}^{\text {surprise }} & =c^{\prime \prime \prime}+\alpha_{i}^{\prime \prime \prime}+\beta_{1}^{\prime \prime \prime} \text { Foreign CapitalFlows }_{i, t-1} \\
& +\beta_{2}^{\prime \prime \prime} \text { Foreign CapitalFlows }_{i, t-1} \times \text { Crisis }^{2008-09} \\
& +\beta_{3}^{\prime \prime \prime} X_{i, t-1}+\beta_{4}^{\prime \prime \prime} \text { Crisis }^{2008-09}+e_{i, t}^{\prime \prime}
\end{aligned}
$$

20) The test results are available upon request. Aizenman, Pinto and Sushko (2013) use a cointegration relationship between non-stationary control variables and GDP per capita in their regression equation. However, we could not find any cointegration relationship among the nonstationary control variables and GDP per capita. This could be due to differences in the data sets and/or specifications. 


\subsection{Estimation results}

Unexpected economic growth, i.e. a GDP growth surprise, is positively related to FDI and foreign bank loans on a contemporaneous basis, as seen in Table 1. In other words, these two types of foreign capital flows tend to amplify the current business cycle in a recipient economy. Specifically, a 1\%p increase in the ratio of FDI to GDP results in an increase of around $0.1 \% \mathrm{p}$ in the unexpected GDP growth rate. Foreign bank loans have a similar size of impact. The flip side of the coin is that outflows or decreases in FDI or foreign bank loans are drags on current actual economic growth. There is, however, no evidence of differences in results between the non-crisis and the crisis periods, as is inferred from the statistical insignificances in the estimated coefficients of the interaction terms between all types of foreign capital flows and the crisis dummy. Meanwhile, foreign portfolio investments such as equity and bond investment do not affect a GDP growth surprise contemporaneously.

In Table 2 we see somewhat different results, with lagged foreign capital flows as in regression equations (3) and (4). An increase in foreign portfolio investment in the previous year causes a smaller GDP growth surprise this year. To be specific, a $1 \%$ p increase in foreign bond or equity investment measured as a percentage of GDP leads to a decrease of around $0.2 \%$ in the following year's GDP growth surprise. In the case of equity investment, this result holds only during a crisis period. Similarly, a $1 \% \mathrm{p}$ increase in the foreign bank loan-to-GDP ratio is estimated to result in a $0.1 \%$ p decline in the next period's GDP growth surprise only during a crisis. This holds even if we control for short-term external debt relative to the foreign exchange reserves. In contrast, FDI in the previous year does not affect GDP growth surprises in the current year in either the crisis or the non-crisis periods. 


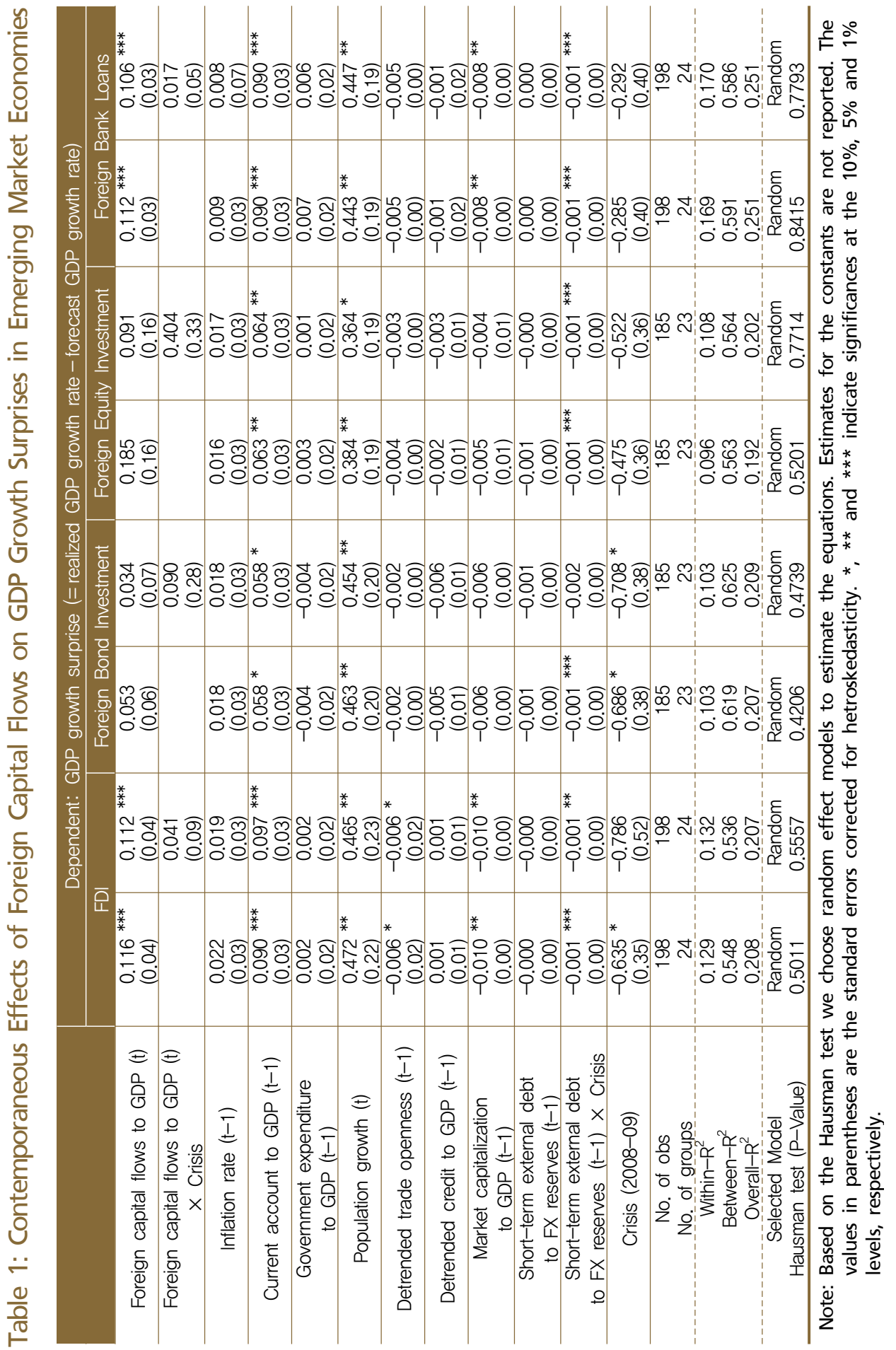




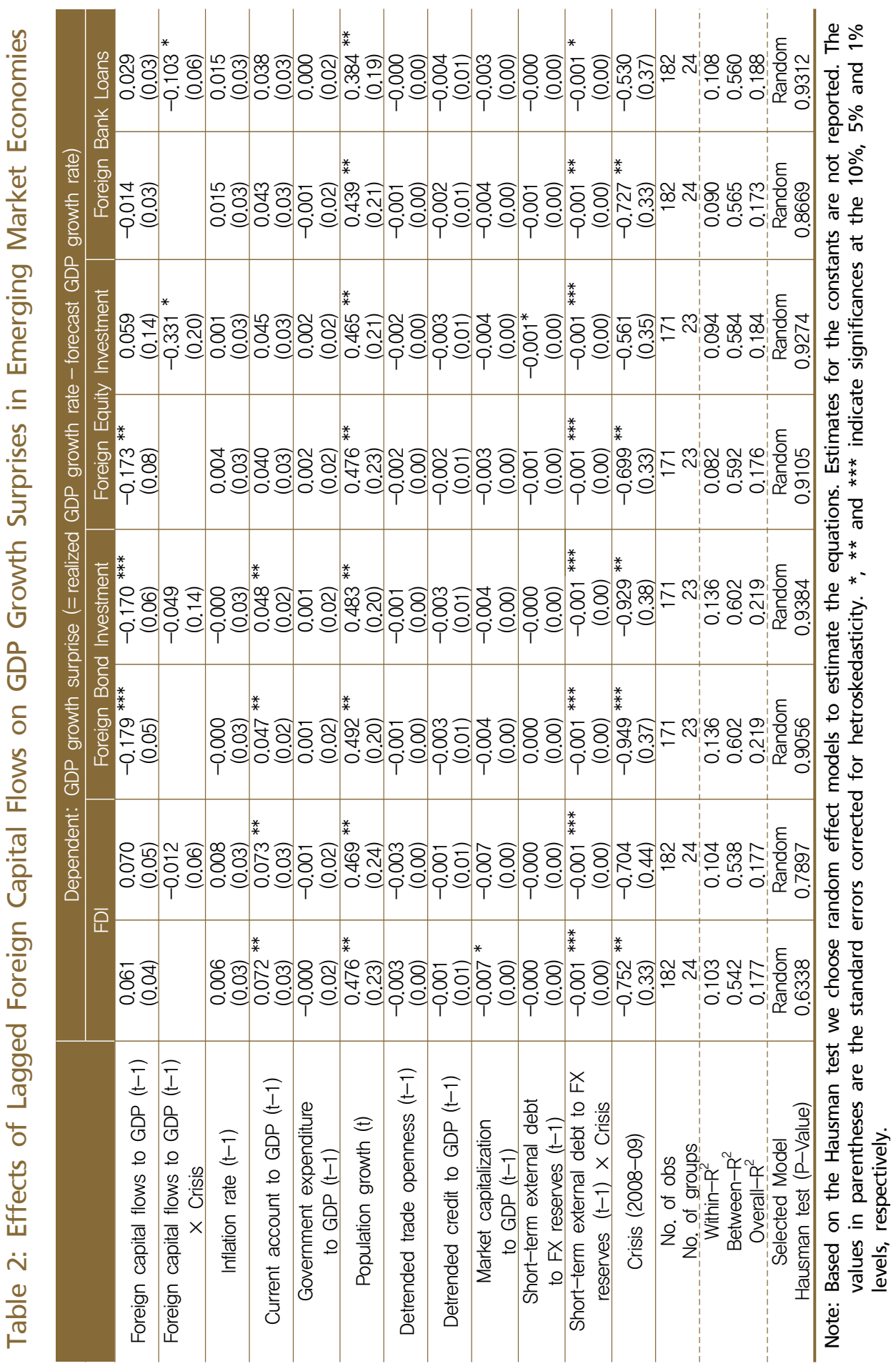


One generically raised question then is whether an increase in lagged foreign capital flows is a cost or a benefit for a recipient EME. We can answer this question by decomposing the factors underlying the smaller GDP growth surprise into two types. First, an increase in foreign capital flows in the previous year is a cost if it leads to a decrease in the actual GDP growth rate this year. This argument is consistent with Choong et al. (2010), who find that foreign portfolio investment has negative effects on economic growth. ${ }^{21)}$ Second, the GDP growth forecast for the next year is either over- or under-estimated, owing to the incorporation of this year's foreign portfolio investment or its effects into the forecast. For example, it is possible that an increase in foreign capital flows to an economy results in an upward bias in its GDP growth forecast. Considering that a policy decision is often based upon economic forecasts, this reminds us of the implication in Reinhart and Reinhart (2009)'s argument that policymakers tend to miscalculate the effects of capital flows on their economies' business cycles.22) Thus both factors contributing to a lower GDP growth surprise - a loss of GDP growth or a bias in the GDP growth forecast in an EME23) - can be considered as costs, while a larger GDP growth surprise from a simultaneous effect of foreign capital flows is considered a cost as explained above.

The other control variables, the current account relative to GDP and population growth, have the expected positive signs with results that are relatively robust. Short-term external debt relative to foreign exchange reserves leads to a lower economic growth rate than expected during a crisis. This result is in line with the growing consensus that excessive short-term debt is one of the main drivers of crises.24) In some cases, lagged market capitalization is negatively

21) In Choong et al. (2010), all of the control variables are taken in differences and lagged one period.

22) Reinhart and Reinhart (2009) argued that policymakers often consider temporary good times owing to capital inflow bonanzas as permanent, a phenomenon reflected in procyclical fiscal policy stances in times of capital flow bonanzas in developing countries.

23) Overall foreign equity investment during this year leads to a smaller GDP growth surprise next year, mainly because of an underestimated GDP growth forecast in the crisis period. On the other hand, foreign bond investment this year seems to bring about a decrease in the rate of actual GDP growth next year in the noncrisis periods, which is then the main driver behind a smaller GDP growth surprise. Refer to Table A.1 and A. 2 in the Appendix.

24) Choong et al. (2010) argue this by referring to past studies such as Rodric and Velasco (1999) and Baharumshah and Thanoon (2006). 
associated with current GDP growth surprises. This is broadly expected from the literature such as Rousseau and Wachtel (2011), Choong et al. (2010), and Aizenman, Pinto and Sushko (2013).25)

\section{Effects of Foreign Capital Flows on Financial Market Volatility}

\subsection{Data and overview}

To investigate the effects of foreign capital flows on stock market and foreign exchange market volatility in an EME, we examine a panel data set of 24 EMEs like in the previous section, albeit with differences in specific variables and data frequency.

Since the amounts of foreign capital flows tend to change very fast, high frequency data is needed to analyse the effects of their volatilities on a recipient economy. Only quarterly foreign capital flow data is available from the IMF BOP statistics, however, and our data set covers 37 quarters from 2005.Q1 to 2014.Q1.26) Foreign capital flows are measured as percentages of nominal GDP, whose quarterly data are mainly from Bloomberg and CEIC. Quarterly GDP growth rates are year-on-year rates from the same sources. Daily stock prices and foreign exchange rates for the economies considered are from Bloomberg, and the quarterly unconditional volatilities of both variables are the quarterly standard deviations of their daily percentage changes. VIX is the Chicago Board Options Exchange Market Volatility Index, a measure of risk aversion conveyed by S\&P 500 stock index option prices. Quarterly interest rate differentials between EMEs and the U.S. are based on three-month interbank interest rates from CEIC and

25) Rousseau and Wachtel (2011) argue that excessive growth in credit leads to a crisis that makes the benefits of financial deepening disappear, while Aizenman, Pinto and Sushko (2013) find that the majority of the real sector is adversely affected by financial contractions after accelerated growth in the financial sector.

26) Emerging Portfolio Fund Research (EPFR) provides weakly data. The coverage is known to be limited, however; according to Miao and Pant (2012), the EPFR data covers around one-half of equity investment and one-eighth of bond investment compared with the balance of payments statistics. Koepke (2013) reports as well that the monthly EPFR data covers about $60 \%$ of international equity investment and $25 \%$ of international bond investment into 30 EMEs. 
Figure 3. Correlations between Foreign Capital Flows and Financial Market Volatility

(Stock Price Volatility)

(Exchange Rate Volatility)

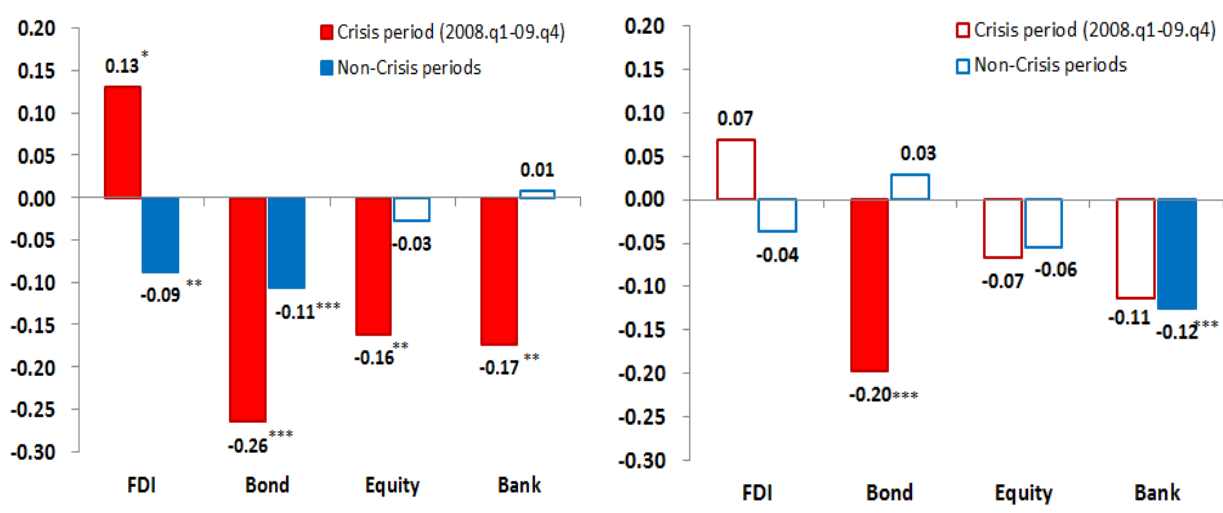

Notes: 1) Stock and exchange rate volatility are measured as the standard deviations of the daily percentage changes over a quarter.

2) $* * *, * *$ and * denote significances at the 1,5 and 10 percent levels, respectively.

Sources: IMF, CEIC, Bloomberg, and authors' calculations

from the webpages of the respective economies' authorities.

As seen from Figure 3, the correlations between foreign capital flows and financial market volatilities are generally negative. A decrease in or outflow of foreign capital investment thus tends to be associated with higher stock price or foreign exchange rate volatility. In some cases the statistical significances or the signs of the correlations differ between the non-crisis periods and the Global Financial Crisis period. This feature needs to be considered in the empirical models.

\subsection{Empirical models}

We focus on the effect of foreign capital flow volatility on a recipient economy's financial market volatility. Our analysis is thus neutral to the directions of the foreign capital flow movements. This simplifies things, in that both surges and stops can be related to higher foreign capital flow volatility. In other words, we assume higher financial market volatility caused by a higher volatility of foreign capital flows as an increased risk from foreign capital flows for the financial system 
of a recipient economy, in contrast to the large body of past studies dealing with the risks of sudden reversals after surges. One issue is that we only have quarterly data on foreign capital flows, which do not allow us to use their quarterly standard deviations as their volatilities as we do for stock prices and foreign exchange rates. To address this we adopt Schwert (1989)'s procedure of calculating the quarterly conditional volatilities of foreign capital flows from the quarterly data themselves.

Specifically, we estimate a 4th-order autoregression (5) for a type of foreign capital flows in a country $\mathrm{i}$ in the first stage. In the next stage we reestimate a 4th-order autoregression (6) for the absolute values of the residuals in the first stage. The regressand $\left|\hat{\epsilon}_{t}^{i}\right|$ is an estimate of the standard deviation of the foreign capital flows after an adjustment using equation $(7)^{27)}$ :

ForeignCapitalFlows $t_{t}^{i}=\sum_{j=1}^{4} \omega_{j}^{i} Q_{j, t}+\sum_{k=1}^{4} \nu_{k}^{i}$ ForeignCapitalFlows $_{t-k}^{i}+\epsilon_{t}^{i}$

where ForeignCapitalFlows $s_{t}^{i}$ is a type of foreign capital flows (measured as a percentage of quarterly GDP) at time $\mathrm{t}$ in an EME i, and $Q_{j, t}$ a dummy for each quarter.

$$
\begin{gathered}
\left|\widehat{\epsilon_{t}^{i}}\right|=\sum_{j=1}^{4} \chi_{j}^{i} Q_{j, t}+\sum_{k=1}^{4} \psi_{k}^{i}\left|\widehat{\epsilon_{t-k}^{i}}\right|+v_{t}^{i} \\
\sigma_{t}^{i}=E\left|\hat{\epsilon_{t}^{i}}\right| \times(2 / \pi)^{(-1 / 2)}
\end{gathered}
$$

We apply this procedure for each type of foreign capital flows in each economy, and also for the GDP growth rates, to get their quarterly conditional volatilities.

To the best of our knowledge there is no previous study that has directly investigated the relationship between foreign capital flow volatility and stock

27) Using this method Schwert (1989) shows that the predicted standard deviations from monthly stock returns are very similar to the predicted standard deviations from daily stock returns. Diebold and Yilmaz (2008) use this methodology for calculating time-varying quarterly GDP volatility and stock market volatility. 
market volatility. We have thus been unable to find a set of control variables identified from past studies for our model specifications. We instead choose control variables related to GDP growth volatility in the recipient economy, the interest rate differential and the global shock together with foreign capital flow volatility. Specifically, we consider a panel model to analyze the effects of foreign capital flow volatility on volatility of the stock market:

$$
\begin{aligned}
\text { Vol }_{i, t}^{\text {StockReturn }} & =\tau_{i}+\gamma_{1} \text { Vol }_{i, t}^{\text {Foreign Capital }} \\
& +\gamma_{2} \text { Vol }_{i, t}^{\text {ForeignCapital }} \times \text { Crisis }^{2008 . q 1-09 . q 4} \\
& +\gamma_{3} \operatorname{Vol}_{i, t}^{\text {GDPgrowth }}+\gamma_{4} \Delta r_{i, t}^{\text {difference }}+\gamma_{5} \Delta \operatorname{VIX}_{i, t} \\
& +\gamma_{6} \operatorname{Vol}_{i, t-1}^{\text {StockReturn }}+\gamma_{7} \operatorname{Vol}_{i, t-2}^{\text {Stocketurn }}+\epsilon_{i, t}
\end{aligned}
$$

where $\operatorname{Vol}_{i, t}^{\text {StockReturn }}$ is the unconditional volatility (standard deviation) of daily stock returns at quarter $\mathrm{t}$ in a country i, Vol ${ }_{i, t}^{\text {Foreign Capital }}$ the conditional volatilities of the four types of foreign capital flows all measured as percentages of GDP, Crisis $^{2008 \cdot q 1-2009 \cdot q 4}$ a crisis dummy, Vol ${ }_{i, t}^{\text {GDPgrowth }}$ the conditional volatility of the GDP growth rate, $\Delta r_{i, t}^{\text {difference }}$ the quarter-on-quarter change in the three-month interbank interest rate differential between the economy $\mathrm{i}$ and the U.S., and $\Delta V I X_{i, t}$ the quarter-on-quarter change in the VIX.

Diebold and Yilmaz (2008) found that volatile macroeconomic fundamentals such as real GDP and real consumption expenditures translate into volatile stock markets. This implies that the estimated coefficient of GDP volatility has a positive sign. Given the deeply integrated global financial markets, the 'summary indicator of global uncertainty or financial stress' implied in the VIX'28) is expected to be positively related to stock market volatility in an EME. Since the VIX measures global shocks more accurately with intensity, in order to avoid a severe collinearity we do not include a GFC dummy separately in the specification. Instead the dummy is interacted with foreign capital flow volatility to find any asymmetry in its effects on stock market volatility between the crisis and the non-crisis periods.

28) Refer to IMF Western Hemisphere Department (2012). Choi (2015) finds that a one standard deviation increase in the VIX causes a $0.7 \%$ decline in output, a $0.2 \%$ p increase in real lending rates, a $0.4 \%$ contraction in domestic credit and a $0.7 \%$ real currency depreciation from trend across 18 EMEs. 
An increase in interest rates relative to those in the U.S. can lead to expanded stock market volatility in that a higher interest rate tends to be negatively associated with stock prices. ${ }^{29)}$

To assess the effects of foreign capital flow volatility on foreign exchange market volatility we use the following panel model, which is constructed similarly to our stock market volatility model:

$$
\begin{aligned}
\operatorname{Vol}_{i, t}^{\text {FX Return }} & =\tau_{i}^{\prime}+\gamma_{1}^{\prime} \text { Vol }_{i, t}^{\text {Foreign Capital }} \\
& +\gamma_{2}^{\prime} \text { Vol }_{i, t}^{\text {ForeignCapital }} \times \text { Crisis }^{2008 . q 1-09 . q 4} \\
& +\gamma_{3}^{\prime} \text { Vol }_{i, t}^{\text {GDPgrowth }}+\gamma_{4}^{\prime} \Delta r_{i, t-1}^{\text {difference }}+\gamma_{5}^{\prime} \Delta \operatorname{VIX}_{i, t}+\epsilon_{i, t}^{\prime}
\end{aligned}
$$

where $\operatorname{Vol}_{i, t}^{\text {FXReturn }}$ is the unconditional volatility (standard deviation) of daily foreign exchange returns at quarter $\mathrm{t}$ in a country $\mathrm{i}$.

Based on Arellano-bond tests we apply Arellano-bond linear dynamic panel data estimators ${ }^{30)}$ to estimate equation (8) with two lags of the dependent variable of stock price volatility, while equation (9) is estimated with random effect or fixed effect panel data estimators without lags of the dependent variable of foreign exchange rate volatility.

\subsection{Estimation results}

As seen from Table 3, the volatilities of all types of foreign capital flows are estimated to be positively associated with stock market volatility in EMEs only during the Global Financial Crisis period. During the crisis, a one percentage point increase in foreign capital flow volatility raises an EME's stock market volatility by $0.12 \%$ p if the foreign capital is for FDI, by $0.09 \%$ p for foreign bond investment, by $0.17 \%$ p for foreign equity investment, and by $0.05 \% \mathrm{p}$ for foreign bank loans. However, we cannot say that foreign equity investment is the riskiest

29) According to modern financial theory, the stock price of a firm is the present value of expected future cash flows discounted at a discount rate. Movements in interest rates affect the discount rate directly, and future cash flows indirectly, by changing the financing cost. See Moya-Martinez et al. (2015).

30) Since we have a small number of cross-sections, 24 emerging economies relative to the number of quarters, 37 , we estimate the equations by variously restricting the number of instruments in order to mitigate possible many moment conditions. We find no qualitative change in the results. 
type during the crisis period simply based on the estimated coefficients, since the probabilities of a one percentage point change in volatility of a type of foreign capital flows differ depending upon the capital flow type.

To compare the sizes of their impacts, we multiply the estimated coefficient of the volatility of each type of foreign capital flows by its standard deviation. This 'semi-standardized coefficient's1) measures how much change is produced in stock market volatility by a one standard deviation change in a type of foreign capital flow volatility. For example, as seen from Figure 4 the change in stock price volatility produced by a one standard deviation change in FDI volatility is $0.13 \%$, which is about $45 \%$ of the impact of one standard deviation of $\triangle$ VIX, the global shock during the Global Financial Crisis. Based upon these calculations, volatility in foreign bank loans has a greater effect than that in foreign equity investment on stock price volatility in a recipient EME, but its effect is smaller than that of $\triangle$ VIX. ${ }^{32)}$ This seems to be contrary to the result based on the original estimated coefficients, but is not actually contrary considering the use of a standardized shock.

An increase in the interest rate differential between a recipient economy and the U.S. tends to cause increased stock market volatility in that economy. This result is possibly due to the negative relationship between interest rates and stock prices. The positive relationship between $\Delta$ VIX and stock market volatility in EMEs is robust as expected.

Positive effects on exchange rate volatility in a recipient economy of volatilities in all types of foreign capital flows appear only during the crisis, a result similar to that for stock market volatility. However, volatilities in three types of foreign capital flows, excepting bond investment, are estimated to have mitigating effects on foreign exchange market volatility during non-crisis periods, a finding that does not hold in the case of stock price volatility. One possible explanation for this is that EMEs tended to intervene in their foreign exchange markets to dampen the speeds of their currency appreciations in the face of increasing capital inflows

31) A standardized coefficient is calculated using a formula (estimated coefficient of control variable $\times$ (standard deviation of control variable $\div$ standard deviation of dependent variable)).

32) The standard deviations of foreign capital flow volatility during the crisis are $1.07 \%$ p for FDI, $1.81 \% \mathrm{p}$ for bond investment, $0.67 \%$ p for equity investment, and $3.43 \%$ p for bank loans. 


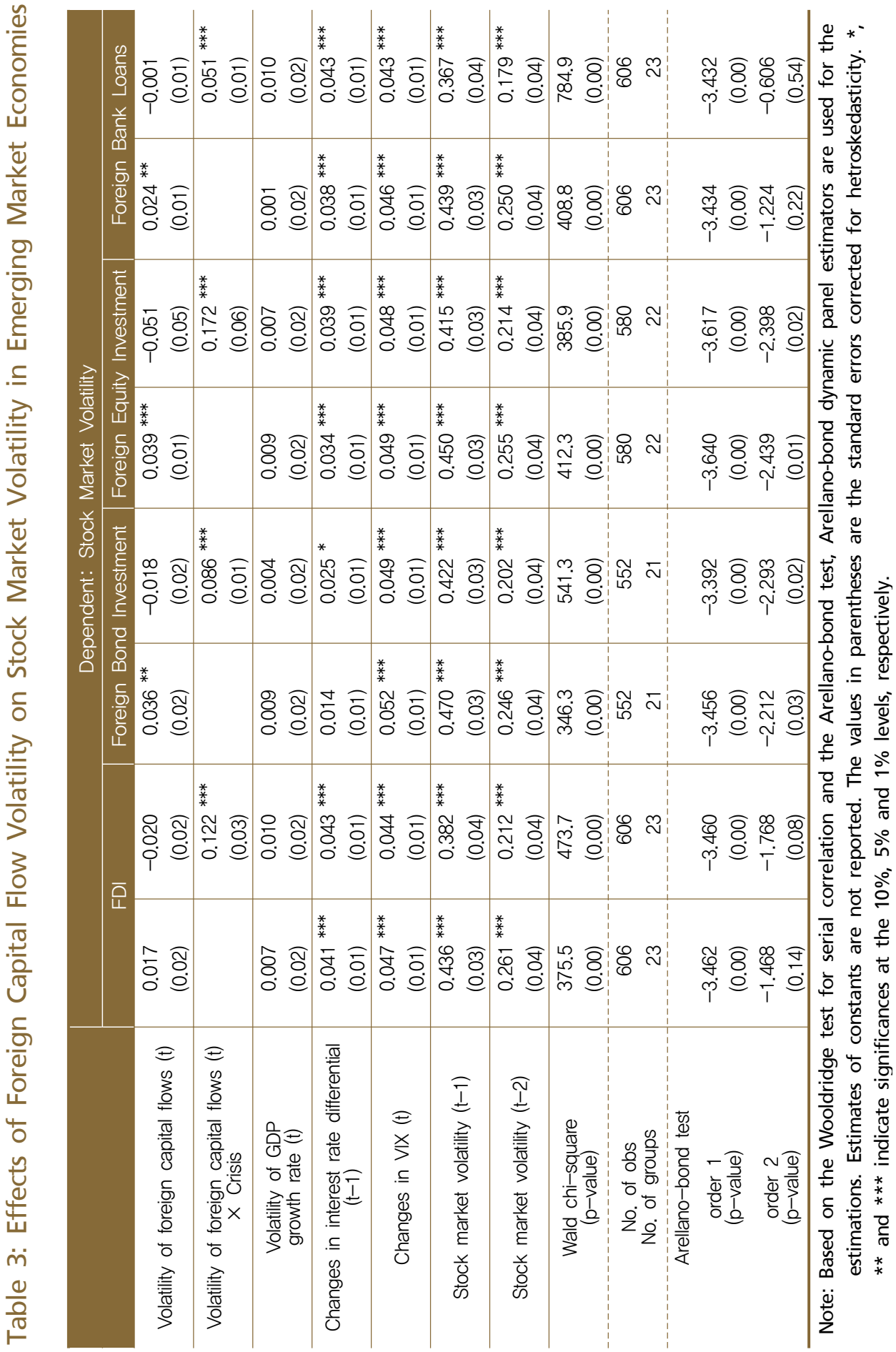




\section{Figure 4: Sizes of Impacts on Stock Market Volatility from Foreign Capital Flow Volatility Shock during the Global Financial Crisis}
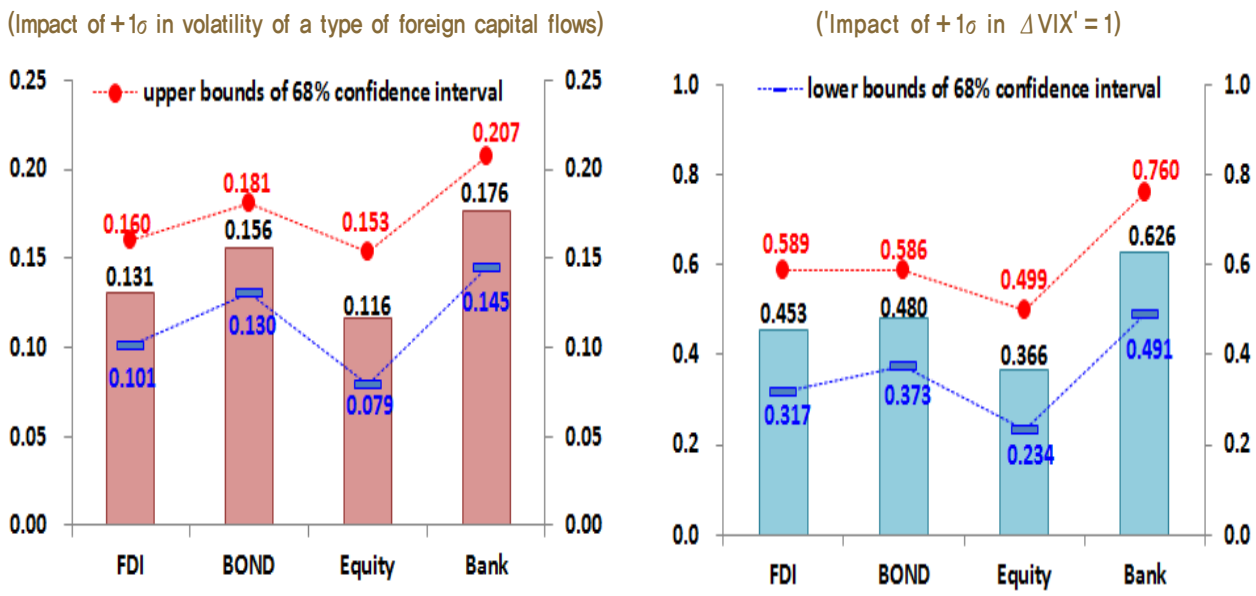

Notes: 1) Based on short-run effects rather than long-run effects.

2) Lefthand figure: 'Semi-standardized' coefficient of a type of foreign capital flow volatility $=$ its estimated coefficient $X$ one standard deviation of it.

3) Righthand figure: Semi-standardized coefficient of foreign capital flow volatility divided by that of $\triangle \mathrm{VIX}$.

4) Confidence intervals are calculated using the delta method.

Source: Authors' estimations

before and after the crisis, and this is then reflected in increases in their foreign exchange reserves. ${ }^{33)}$ A lower exchange rate volatility can thus go together with higher foreign capital flow volatility caused by increased capital inflows during a non-crisis period.

Specifically, a one percentage point increase in foreign capital flow volatility pushes foreign exchange rate volatility in a recipient economy up by $0.06 \%$ p for FDI, $0.08 \%$ p for bond investment, $0.07 \%$ p for equity investment, and $0.02 \%$ p for bank loans during the crisis period, as seen in Table 4. During a non-crisis period, in contrast, a one percentage point increase in foreign capital flow volatility leads to reductions in exchange rate volatility of $0.03 \%$ p for $\mathrm{FDI}, 0.10 \%$ p for equity

33) Malloy (2013) finds that the competitiveness motive together with short-run smoothing and precautionary motives also impacts foreign exchange rate intervention decisions in EMEs. This competitiveness motive may induce a lower degree of foreign exchange rate volatility through interventions in the face of rising tides of foreign capital flows. 
Figure 5: Sizes of Impacts on Foreign Exchange Market Volatility from Foreign Capital Flow Volatility Shock during the Global Financial Crisis
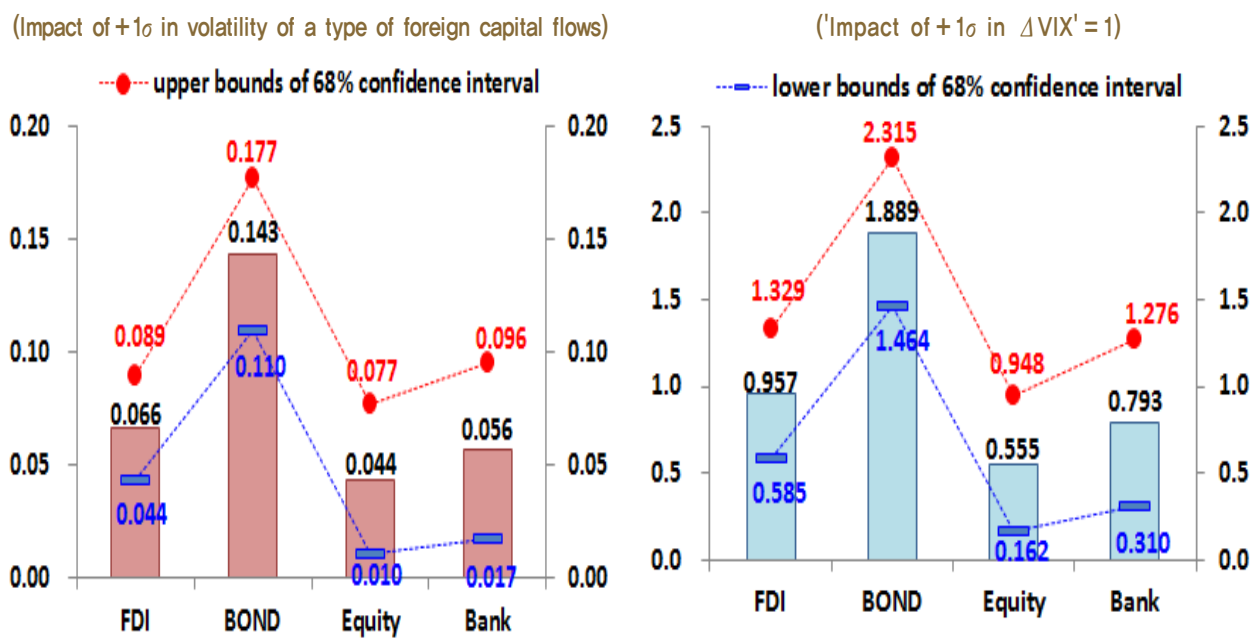

Notes: 1) Left hand side figure: 'Semi-standardized' coefficient of a type of foreign capital flow volatility $=$ its estimated coefficient $X$ one standard deviation of it.

2) Right hand side figure: Semi-standardized coefficient of foreign capital flow volatility divided by that of $\triangle \mathrm{VIX}$.

3) Confidence intervals are calculated using the delta method.

Source: Authors' estimations

investment, and $0.01 \%$ p for bank loans. Based on the 'semi-standardized impacts' as explained above and shown in Figure 5, foreign bond investment volatility has the strongest impact on FX rate volatility during the crisis period, and the size of impact is greater than that of $\triangle \mathrm{VIX}$, a global financial market shock with the assumption of one standard deviation change in both variables. This result is consistent with the theory of interest rate parity that implies a strong relationship between yields of bonds and foreign exchange rates. The volatilities of the other three types of foreign capital flows to EMEs have similar sizes of impacts on foreign exchange rate volatility during the crisis. 


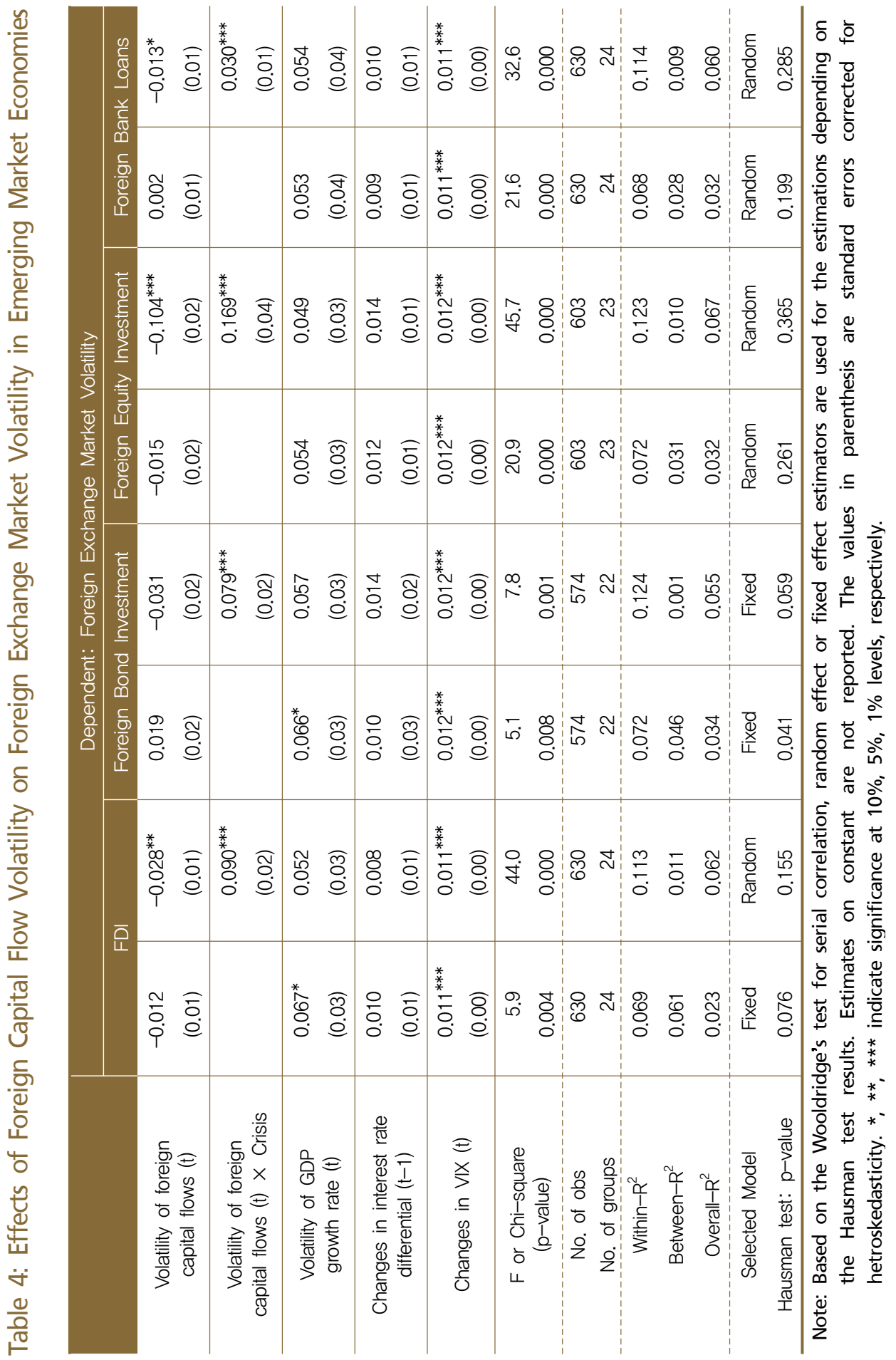




\section{IV . Conclusions}

In this paper, we examine the impact of four types of foreign capital flows on economic growth surprise and financial market volatility in 24 EMEs and get to three main findings. First, FDI and foreign bank loans turn out to be positively associated with GDP growth surprises on a contemporaneous basis, while foreign bond and equity investments tend to negatively affect the next year's GDP growth surprise. This implies that fluctuations in FDI and foreign bank loans can amplify business cycles in the recipient economies, while a boom in foreign portfolio investment can result in lower GDP growth than expected in the following year.

Second, increases in volatility of all four types of foreign capital flows bring about higher stock market volatility in an EME only during a crisis period such as the Global Financial Crisis. Volatility in foreign bank loans is likely to have a larger impact here than will volatility in foreign equity investment, assuming one standard deviation increases in volatility of all four types of foreign capital flows. This is in line with the consensus wisdom that a debt type of capital flow is riskier than an equity type for an EME during a period of global financial stress.

Third, elevated volatilities of three types of foreign capital flows excepting bond investment amplify foreign exchange market volatility during a crisis period while in contrast mitigating it during a non-crisis period. Foreign bond investment volatility is positively linked to foreign exchange rate volatility only during a crisis. However, assuming one standard deviation increases in volatility of all types of foreign capital flows during a crisis, foreign bond investment volatility has the strongest impact on foreign exchange market volatility.

This evidence of possible costs of foreign capital flows in EMEs should motivate their policymakers to introduce capital flow management measures or macroprudential measures to ensure macroeconomic stability and financial stability in their economies. ${ }^{34)}$ If properly implemented, such measures can be expected to help mitigate excessive fluctuations in foreign capital flows. They are particularly useful when the time required for macroeconomic tools such as

34) "While capital flow management measures aim to contain the scale or influence the composition of capital flows, macroprudential measures are primarily to limit systemic risks and maintain financial system stability.” See IMF (2013) for details. 
monetary and fiscal policies to take effect is longer than desired and/or when the room for them to affect foreign capital flows is limited. ${ }^{35)}$ In the face of economic sluggishness, for example, an EME will have limited room for employing monetary policy to curb large outflows of foreign capital following a global shock like US monetary policy normalization. In such a case, capital flow management measures such as Brazil's taxes on certain types of foreign capital flows, Indonesia's holding period on central bank bond purchases, and Korea's leverage caps on banks' FX derivatives positions could give macroeconomic policy room to work. Thus, capital flow management or macroprudential measures can be expected to limit the costs from foreign capital flows while allowing realization of their benefits. We leave to future research analysis of the effectiveness of such measures in curbing the possible costs of foreign capital flows. 


\section{References}

Aizenman, J., Y. Jinjarak, and D. Park (2013), "Capital Flows and Economic Growth in the Era of Financial Integration and Crisis, 1990-2010," Open Economic Review, Vol. 24, pp. 371-396.

Aizenman, J., B. Pinto, and V. Sushko (2013), "Financial Sector Ups and Downs and the Real Sector in the Open Economy: Up by the Stairs, Down by the Parachute," Emerging Market Review, Vol. 16, pp. 1-30.

Arteta, C., B. Eichengreen, and C. Wyplosz (2001), "When Does Capital Account Liberalization Help More Than It Hurts?” NBER Working Paper, No. 8414.

BIS CGFS (Committee on the Global Financial System) (2009), "Capital Flows and Emerging Market Economies," CGFS Papers, No. 33.

Borio, C. (2014), "The Financial Cycle and Macroeconomics: What Have We Learnt?” Journal of Banking \& Finance, Vol. 45, pp. 182-198.

Caballero, J. A. (2014), "Do Surges in International Capital Inflows Influence the Likelihood of Banking Crises?” The Economic Journal, doi: 10.1111/ecoj.12.172.

Cecchetti, S. G., and E. Kharroubi (2012), "Reassessing the Impact of Finance on Growth," BIS Working Papers, No. 381.

Chinn, M. D., and H. Ito (2006), "What Matters for Financial Development? Capital Controls, Institutions, and Interactions," Journal of Development Economics, Vol. 81, Issue 1, pp. 163-192.

Choi, S. (2015), "The Impact of VIX Shocks on Emerging Market Economies: A Flight to Quality Mechanism," manuscript.

Choong, C.-K., A. Z. Baharumshah, Z. Yusop, and M. S. Habibullah (2010), "Private Capital Flows, Stock Market and Economic Growth in Developed and Developing Countries: A Comparative Analysis," Japan and the World Economy, Vol. 22, pp. 107-117. 
Claessens, S., M. A. Kose, and M. E. Terrones (2011), "How Do Business and Financial Cycles Interact?" IMF Working Paper, No. WP/11/88.

Diebold, F. X., and K. Yilmaz (2008), "Macroeconomic Volatility and Stock Market Volatility, Worldwide," NBER Working Paper, No. 14269.

Eichengreen, B. (2001), "Capital Account Liberalization: What Do Cross-country Studies Tell Us?" The World Bank Economic Review, Vol. 16, No. 3, pp. 341-365.

Henry, P. B. (2007), "Capital Account Liberalization: Theory, Evidence, and Speculation," Journal of Economic Literature, Vol. 45, pp. 887-935.

IMF (2013), "Guidance Note for the Liberalization and Management of Capital Flows."

IMF Western Hemisphere Department (2012), "The Effects of Global Financial Shocks on Output in Latin America," Regional Economic Outlook Analytical Notes, Spring 2012.

Kim, K., and S. Mitra (2014), "Real and Financial Vulnerabilities from Crossborder Banking Linkages,” IMF Working Paper, No. WP/14/136.

King, R. G., and R. Levine (1993), "Finance and Growth: Schumpeter Might Be Right," The Quarterly Journal of Economics, Vol. 108, No. 3, pp. 717-737.

Koepke, R. (2013), "Quantifying the Fed's Impact on Capital Flows to EMs," IIF Research Note.

Kose M. A., E. S. Prasad, K. Rogoff, and S.-J. Wei (2009), "Financial Globalization: A Reappraisal," IMF Staff Papers, Vol. 56, No. 1.

Malloy, M. (2013), “Factors Influencing Emerging Market Central Banks' Decision to Intervene in Foreign Exchange Markets," IMF Working Paper, No. WP/13/70.

Miao, Y., and M. Pant (2012), "Coincident Indicators of Capital Flows," IMF Working Paper, No. WP/12/55. 
Montiel, P. J. (2014), “Capital Flows: Issues and Policies,” Open Economic Review, Vol. 25, pp. 595-633.

Moya-Martinez, P., R. Ferrer-Lap̃eña, and F. Escribano-Sotos (2015), "Interest Rate Changes and Stock Returns in Spain: A Wavelet Analysis," BRQ Business Research Quarterly, Vol. 18, pp. 95-110.

Reinhart, C. M., and V. R. Reinhart (2009), "Capital Flow Bonanzas: An Encompassing View of the Past and Present," NBER International Seminar on Macroeconomics 2008, pp. 9-62.

Rousseau, P. L., and P. Wachtel (2011), "What Is Happening to the Impact of Financial Deepening on Economic Growth?” Economic Inquiry, Vol. 49, No. 1, pp. 276-288.

Schwert, G. William (1989), "Why Does Stock Market Volatility Change Over Time?” The Journal of Finance, Vol. 44, No. 5, pp. 1115-1153.

Vo, Xuan-Vinh (2010), "Net Private Capital Flows and Economic Growth - The Case of Emerging Asian Economics," Applied Economics, Vol. 42, pp. 3135-3146. 


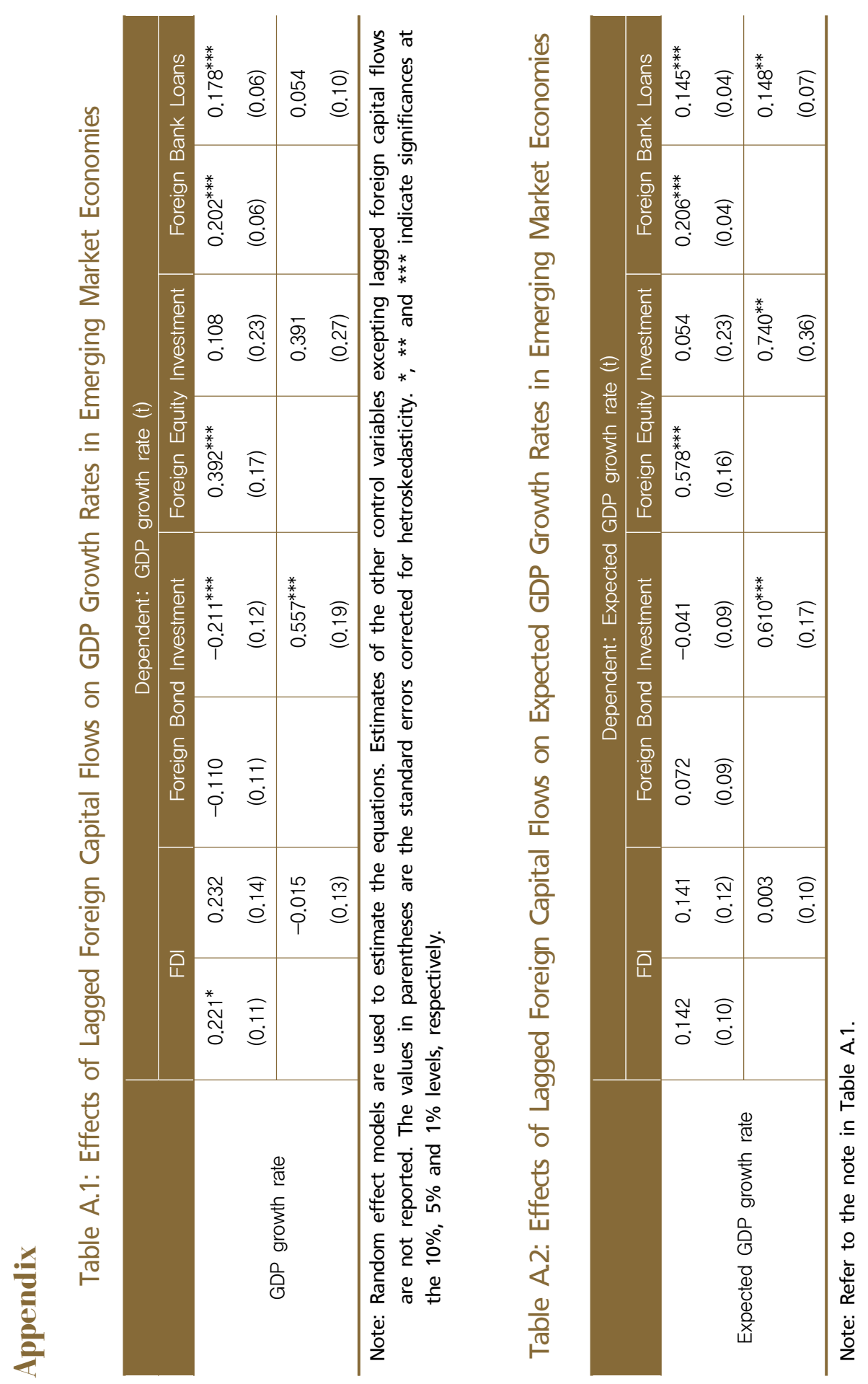


Figure A.1: Foreign Capital Flows and GDP Growth Surprises

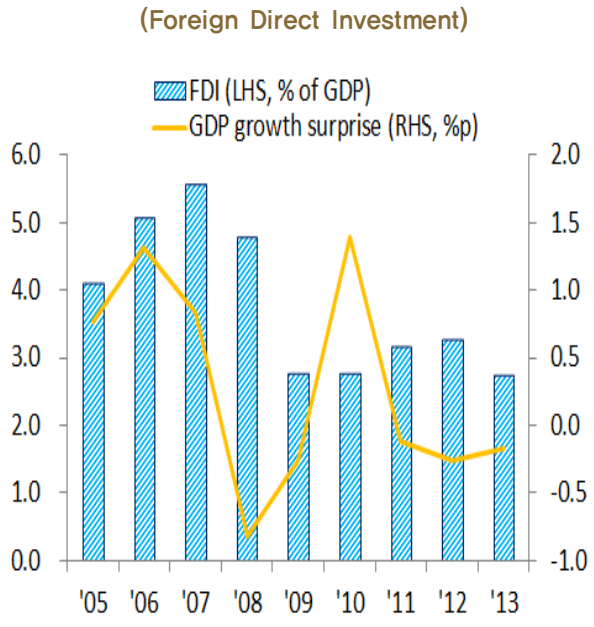

(Foreign Equity Investment)

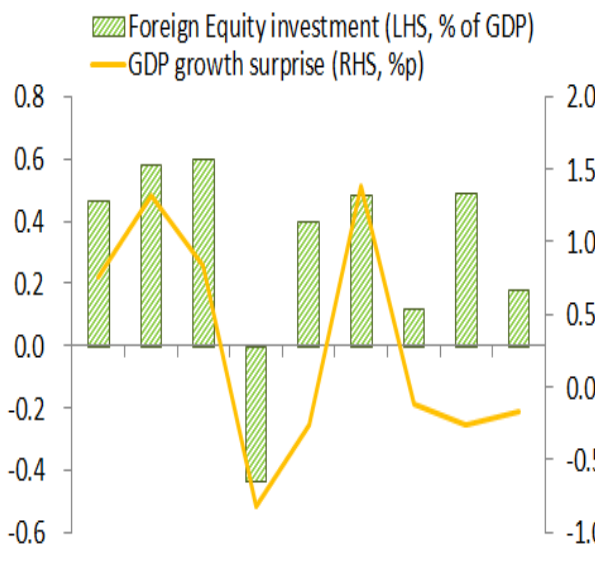

'05 '06 '07 '08 '09 '10 '11 '12 '13
(Foreign Bond Investment)

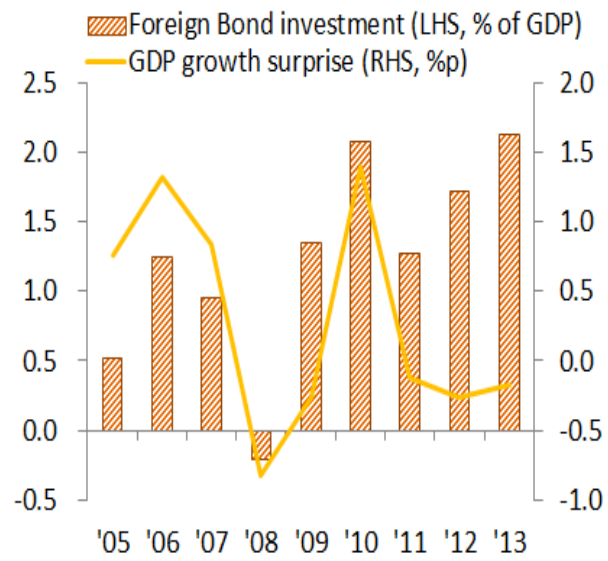

(Foreign Bank Loans)

UID Foreign bank loans (LHS, \% of GDP) - GDP growth surprise (RHS, \%p)

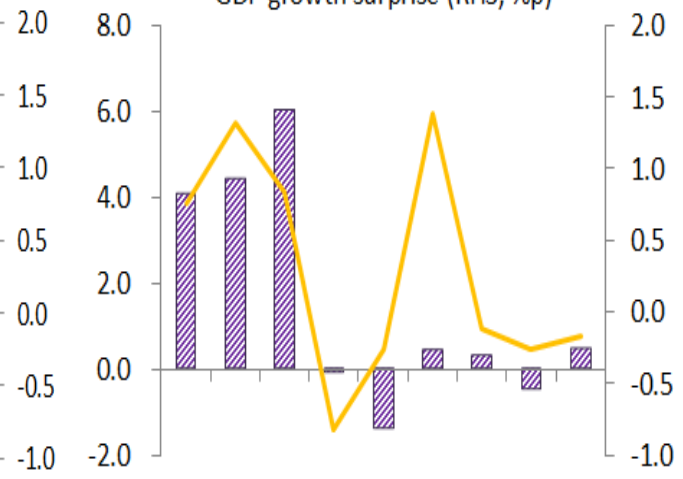

'05 '06 '07 '08 '09 '10 '11 '12 '13

Notes: 1) A GDP growth surprise is defined as the difference between the realized GDP growth rate and the expected GDP growth rate.

2) Based on simple averages over 24 emerging market economies.

Sources: IMF, BIS, World Bank and authors' calculations 


\section{$<$ Abstract in Korean $>$ \\ 신흥국에서의 해외자본 유출입 비용: \\ 예상치 못한 경제성장과 금융시장 변동성의 증대 \\ 윤 경 수*, 김 자 영**}

지난 10 여년 동안 신흥국은 해외자본 유출입이 크게 늘어나면서 경제성장 및 금융시장의 변동성도 높아지는 것을 경험하였다. 이에 따라 본고는 해외자본 유출입이 신흥국 경제에 초래할 수 있는 비용을 거시경제안정과 금융안정 관점에서 분석하였다. 해외자본 유출입이 예상치 못한 경제성장 $=\mathrm{GDP}$ 성장률 실제치 전망치)에 미치는 영향을 추정한 결과 FDI나 은행차입의 유입이 증가하면 당기의 예상치 못한 경제성장도 확대되는 것으로 나타났다. 이에 비해 채권 및 주식자금은 시차를 두고 경제성장에 부정적 영향을 미치거나 경제성장 전망의 과대 혹은 과소평가의 원인이 될 수 있는 것으로 나타났다.

한편 위기시에는 해외자본 유출입의 변동성 증대가 주식시장의 변동성 증대로 이어지며 그 증대폭은 은행차입이 주식자금보다 클 수 있는 것으로 나타났다. FDI, 주식자금, 은행차입은 위기시 외환시장의 변동성을 증대시키지만 위기 이외 기간에는 오히려 이를 완화시키는 것으로 나타났다. 채권자금의 변동성 증대는 위기 기간에 환율 변동성을 가장 크게 증대시키는 요인이나 위기 기간이 아닌 경우에는 영향이 나타나지 않았다. 따라서 신흥국은 해외자본의 이익을 최대한 향유하면서 발생 가능한 비용은 최소화할 수 있도록 적절한 거시건전성정책 혹은 자본유출입 관리정책을 활용할 필요가 있다.

핵심 주제어: 해외자본 유출입, 예상치 못한 경제성장, 주가 변동성, 환율 변동성

JEL Classification: E2, F21, F3, G1, O47

* 한국은행 국제국 국제금융연구팀 차장

** 한국은행 부산본부 경제조사팀 과장

이 연구내용은 집필자의 개인의견이며 한국은행의 공식견해와 무관합니다. 따라서 본 논문의 내용을 보도하거나 인용할 경우에는 집필자명을 반드시 명시하여 주시기 바랍니다. 